University of Nebraska - Lincoln

DigitalCommons@University of Nebraska - Lincoln

$11-1957$

\title{
Preliminary estimate of the underflow across the South Dakota- Nebraska State line in the Niobrara River and Ponca Creek drainage basins
}
E. C. Reed
C. F. Keech

Follow this and additional works at: https://digitalcommons.unl.edu/conservationsurvey

Part of the Geology Commons, Geomorphology Commons, Hydrology Commons, Paleontology Commons, Sedimentology Commons, Soil Science Commons, and the Stratigraphy Commons

Reed, E. C. and Keech, C. F., "Preliminary estimate of the underflow across the South Dakota-Nebraska State line in the Niobrara River and Ponca Creek drainage basins" (1957). Conservation and Survey Division. 53.

https://digitalcommons.unl.edu/conservationsurvey/53

This Article is brought to you for free and open access by the Natural Resources, School of at DigitalCommons@University of Nebraska - Lincoln. It has been accepted for inclusion in Conservation and Survey Division by an authorized administrator of DigitalCommons@University of Nebraska - Lincoln. 
UNITED STATES DEPARTMENT OF THE INTERIOR

GEOLOGICAL SURVEY

PREIIMINARY ESTIMATE OF THE UNDERFLON ACROSS THE SOUTH DAKOTANEBRASKA STATE LINE IN THE NIOBRARA RIVER AND PONCA CREEK DRAINAGE BASINS

By $E_{0}$ C. Reed and C. F. Keech

Lincoin, Nebraska

November 1957 


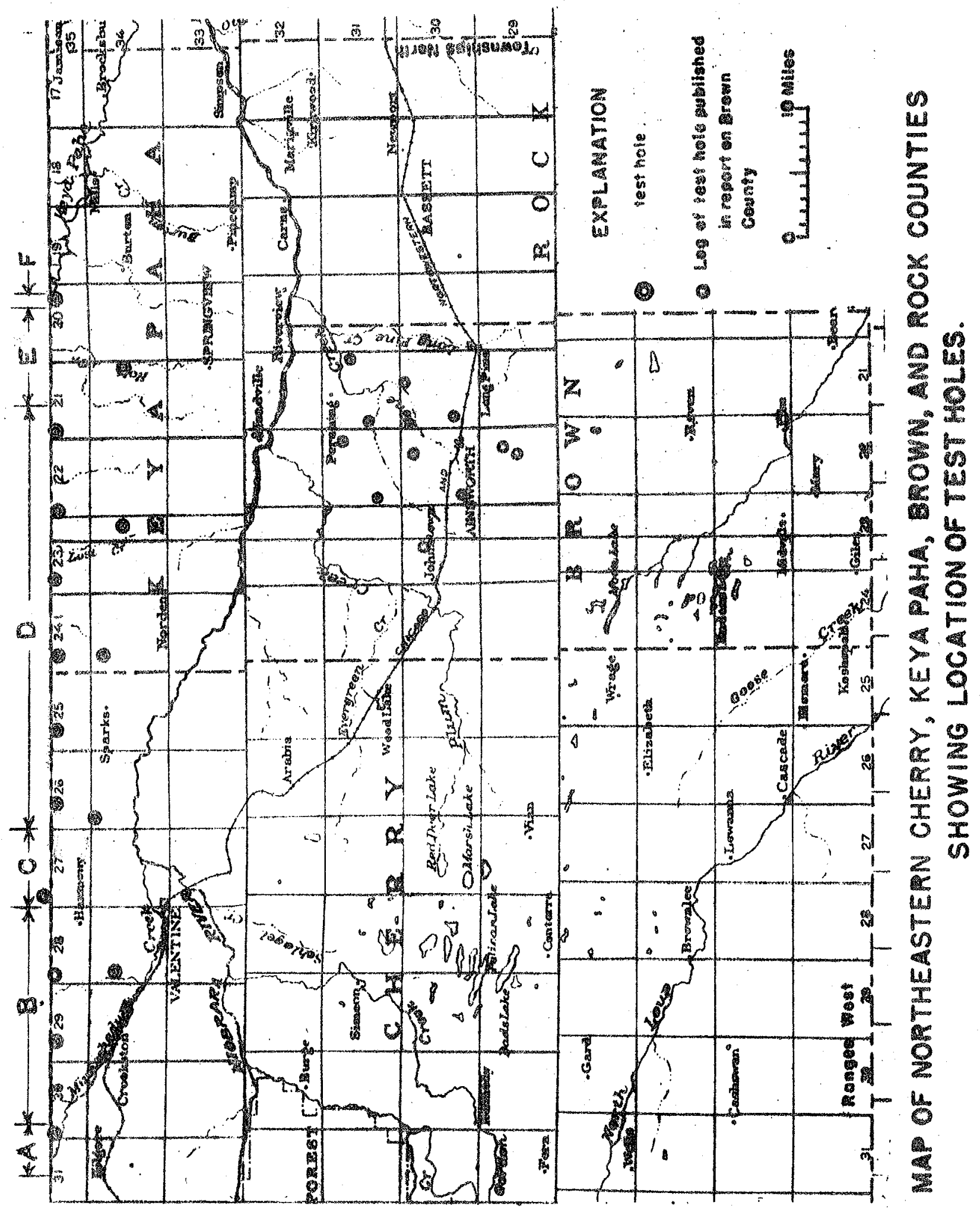


PRELIMINARY ESTIMATE OF THE UNDERFLON ACROSS THE SOUTH DAKOTA NEBRASKA STATE IINE IN THE NIOBRARA RIVER AND PONCA CREEK DRAINAGE BASINS By E.C.Reedl/ and C.F. Keeche/

\section{Introduction}

The purpose of this paper is to estimate the amount of ground water flow ing across the South Dakota-Nebraska State line within the Niobrara River basin, including the Ponca Creek basin. The study was made at the request of the Niobrare River Compact Commission. The estimates given in the paper are preliminary and subject to revision.

\section{Geologic Setting}

The Niobrara River basin lies across the South DakotamNebraska State line and is underlain by deposits whose wateroyielding properites extend over a considerable range of values. A longitudinal section of the waterobearing for mations is somewhat wedge shaped. The trater-bearing formations are about 205 feet thick where the State line crosses the western boundary of the Minnechaduza Creek basin; the formations progressively diminish in thickness eastward for about 60 miles and then essentially disappear. The watermbearing deposits rest upon older formations that are almost impervious.

Surficial deposits of Quaternary age and immediately underlying deposits of the Ogallala formation of Tertiary age are the important water formations. The White River group (Chadron and Brule formations), also of Tertiary age, underlie the Ogallala formation. The Pierre shale of Cretaceous If Director of the Conservation and Survey Division of the University of Nebraska. Nebraska.

2/ District Engineex, Ground Water Branch, U。 S。 Geological Survey,

Openofile report. Not reviewed for conformance with standards and now menclature of the Geological Surrey. Subject to revision. 
age underiles the Tertiary deposits. The White River group and the Pierre shale have very low permeabilitids and can transmit water at only a very slow rate; the water they can yigld is relabively undmportato

In addition to the wedge shaped section of waterobearing deposits just described, thin sections of permeable 1 luvial materials overite the bedrock under the valleys of the Keya Pana River and Ponca Creek. These deposits are of sufficient saturated thickness at most places to keided water to wells of sma11 capacity。

\section{Determination of Under 1 low by the Appliestion of Darcy ${ }^{0}$ Law}

Lateral movement of the ground water is in the direction of the slope of the water table. Plate 1 shows by contour lines the approximate configuration of the water table in the vicinitry of the South Dakota Nebraska State line. The waterotable contoux Iines are based upon the altitude of the watex level In selected wells throughout the area. The altitude of the measuring point of each well was determined from topographic maps in areas that had been topographically mapped and by means of aneroid barometers in other areas.

The amount of watex that flows through an aquifer is proportional to the slope of the water table, the pexmeability of the aquifer, and the crosssece tional area through which the water moves. The field coefficient of permeability of an aquifer may be expressed as the rate of flow of watex, in gallons per day, through a cross section 1 foot high and 1 mile wide undex a hydraulic gradient of 1 foot per mile and at the prevaling groundewater temperature. 
Two factors were considered in estimating the amount of groundwater movement across the Nebrassigasouh Dakota IIne between Minnechaduma Creek and the Keya Paka River. They are (1) the hydralic gxadients at right angles to the state line determined from the regional waterotable contour map (plo l), and (2) the transmissibilities of the permeable materials lying below the water table, which were estimated from the testohol xecords. If additional water table eleyations are obtaned, especially in South Dakota, the hydraulic gradients may be determined more accurstely but the resulting revisions likely wiIl be unimportant. The tronsmissibilities were determined by estimating the coefficient of permeability of each type of relatively permeable material be low the water table, multiplying this figure by the number of feet of the material drilled, and totaling the results for all computations for each test hole. The estimates of permeability are thought to be reasonable but could be substantially in error.

The field coefficients of permeabilitigy assigned to various types of material are based on a comprehensive study of testwhole cuttings. Texture, cementation, and other factors were taken inta account, Assigned field coefficlents of permeability, in gallons pex day pers square foot, are as shown by the following general scale:

Sand and gravel (medium sand to medium gravel) 1,500 Sand and gravel (finemmedium asud to fine growel) 1,200 Very coarse sand $900-1,000$ Mediun to coarse sand 750 Medium sand 500 Fine to medium sand Fine sand $250=300$ Relatively unconsolidated sandstone 175 Fine- to medium gxained sandstone 150 Fine-grained sandstone Siltstone to sandstone 125 clay, silt, and silitstone 
The permeability values assigned to the different materials are probably 2ccurate within 20 percent but cannot be graranted to be so. The computed range in estimated groundwater movement is shom in table 1 ; on the basis of experfence and general knowledge of the area, however, the lower rather than the higher palue is believed to be more nearly correct.

For purposes of computation, the State line was divided into six sego ments in exch of which the general conditions of gradient, transmissibility, and direction of movement are similar. Starting from Minnechaduza Creek, the firat segment (A) is 2 miles long and has comparatively low gradients but comparatively high transmissibility; the second segment (B) is 17 miles long, with low transmissibilities and high gradients; the third segment (c) is 6 miles Iong and is essentially along the groundwater divide; the fourth segment (D) is 32.5 miles long, with high gradients and generally low trans missibilities; the firth segment (E) is 8.5 miles long and is an area where shale is at or near the surface and where there is little or no groundwater movement; and the sixth segment $(F)$ is the Keya Paha Valley bottom land, about 1,100 feet in width, with high transmissibilities and low gradients. The ground-kater novement across segments $A, B$, and $F$ is toward Nebraska and the groundwater movement across Segment $D$ is toward South Dakota. The groundwater movement across segments $C$ and $E$ is believed to be insignificant. The computation and summation of the groundowater morement across these sega ments is summarized in table 1 . 


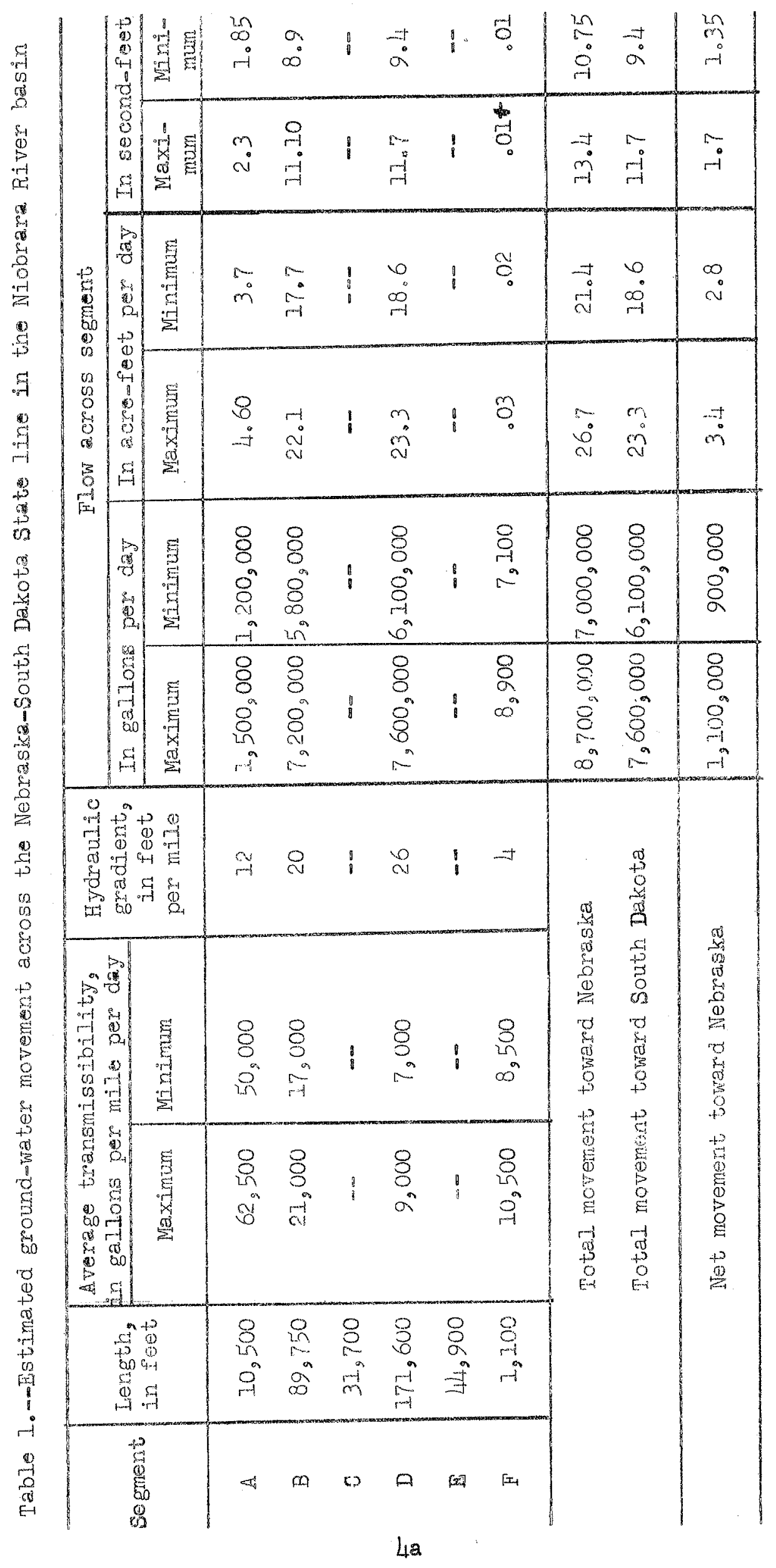


Determination of Underslow by the Groundwatex Discharge Hethod, Minnechedus $6 r e \mathrm{r}$ Basir

The Minnechadus Greek basin Inelwdes about 303 square miles, of which 42 percent or about 127 square miles so sn south Dakota and 58 percent or 176 square miles is in Nebrogkan.

Measurements of the flow of Minnechadua Creek are made at a gaging station at Valentine, Nebro, near the mouth of the creek. The flow in Minnew chadura Creek during pexiods of lithle or no precipitition is groundwater discharge。 During dry periods in winter months the flow in the creek reprew sents the totgl groundowater discharge from the basin because essentially no gxourd water is being discharged by evapotzanspirotion The discharga of ground water received from precipitation, the only woures of recharge in the basin, is believed to be at a generally uniform rate because, owing to the relatively low xate of garoundwater movement, the ixregularities in the reate and anount of recharge are smoothed out and averged before the discharge points or areas are reached.

Records of the U. S. Weather Bureau show that Nopember 1955 was very dry; oniy 0.06 inch of precipitatoon fell at Valentine during the month. Therefore, it can be assumed that no water was contributed to the flow in the creek by direct runoff. The arerage flow in Ninnechaduza Creek at the Val-o entine gaging station duroing November 1955 was 28.1 second feet, or about 55.5 acrewfeet per day; this flow is believed to be measure of the total ground water discharged from the entire Minnechadua Creek basin and to represent the average rate of groundowater discharge from the basin. As but little 
ground water is discharged from the basin by other than natural means, this average rate of groundowater discharge, therefore, essentially equals the average rate of groundwater recharge. Then, if the recharge from precipio tation is assumed to be unfform over the entire basin, 42 percent of the rew charge or about 23.3 creafeet per day occurs in South Dakota. As the groundo water discharge is essentially all in Nebraska, it follows that about 23.3 acreo feet (11.7 secondwfeet) of water per day is moving across the state line from South Dakota and into Nebraska in the Minnechaduza Creek basin.

\section{Recharge from Precipitation}

If the recharge to the Minnechadua Creek basin is 55.5 acrem feet pex day as computed above, the recharge to the basin in 1 year is about 0.105 feet on 303 square miles; that is, about 1.25 inches of the average yearly prem cipitation recharges the groundwwater reservoir. According to the Weather Bureau, the average annual precipitation at Valentine is 18.26 inches; thus, the recharge to ground water is about 7 percent of the precipitation. This value for recharge from precipitation, considering similar data from other areas and considering the topography, soil, and geology of the basin, is beo lieved to be reasonably accurate.

\section{Effect of Soils and Geology}

The solls of the Minnechaduza Creek basin are sandy and permeable and permit water from precipitation to percolate easily to the water table. 
The geologic formations upon which the soils are developed are of sufficient permeability and thickness to provide a laxge capacity for ground-water stor age。

The soils of the Keyz Paha River bas composed laxgely of dense clay, axe almost opposite to those in the Minne chadura Creek basino The solls are hard and are low in absorptive qualities, and rointall Is rapidy discharged by direct runoff. Becharge to the groundo water reservoly from precipitation in these basins is small. Furthermore, the soils mantle formations of low permeability whinh propide but small capa city for groundwater storage. Except in the shallow alluvial fills in the valleys of the Keya pane River and Ponca Creek, there are no saturated materials of sufficient thickness to yield signjficant amounts of water to wells. No potential for large groundwater development exists in these basins, and the amount of ground water moving across the State line in then is very small.

\section{Summary}

Analysis of the railable data indicates that part of the ground water that oxiginates in South Dakota moves as underfor across the State Iins Into Nebrsska and, likewise, part of the ground water that oxiginates in Nebraska moves into South Dakot: The amount of ground water moving into Nebraska is estimated to be about 11 secondofeet, most of which originates in the Minnechaduza Creek basin. The amound moying into South Dakota is estimated to be about 9.5 secondoieet, most of which originates in the Keya Paha Rjver basin. The net movement into Nebraska is between $1_{0} 0$ and 1.5 secondcoet. 


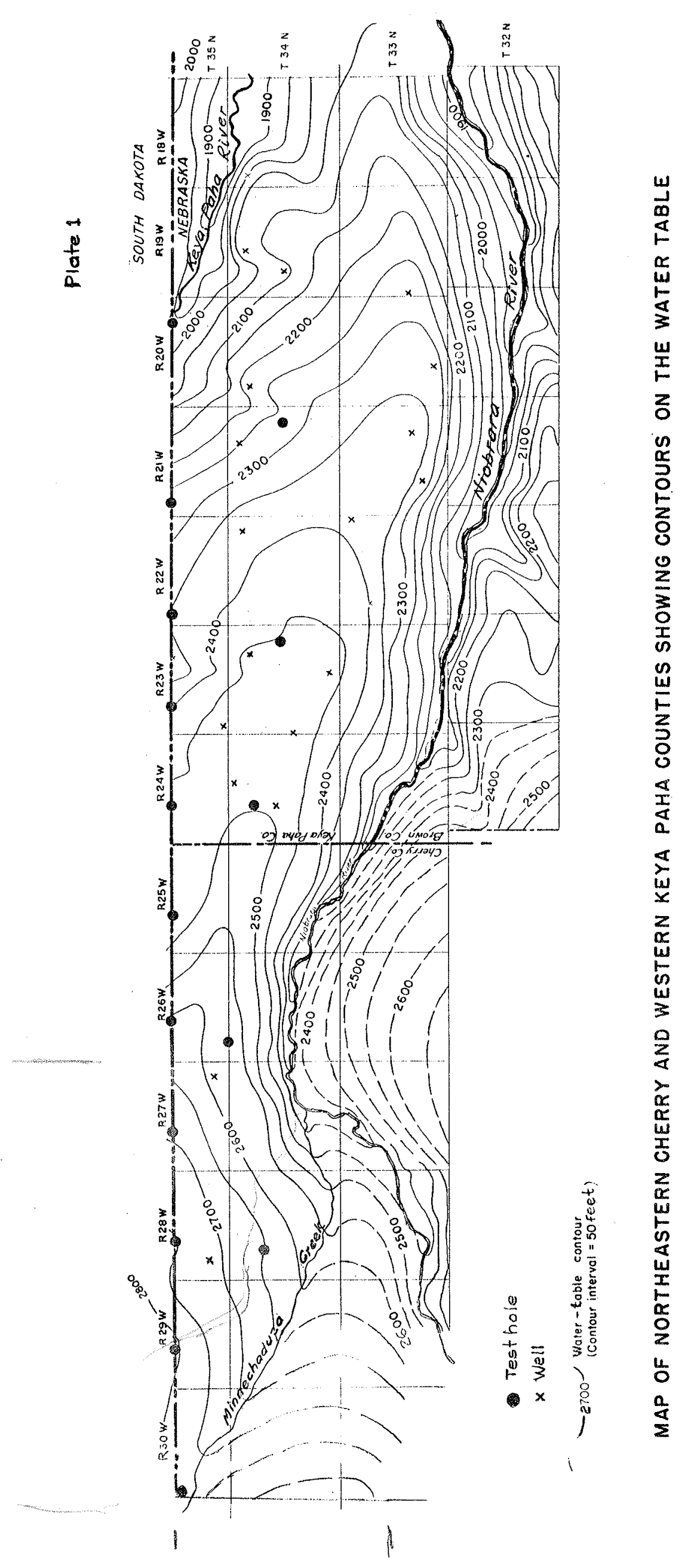

